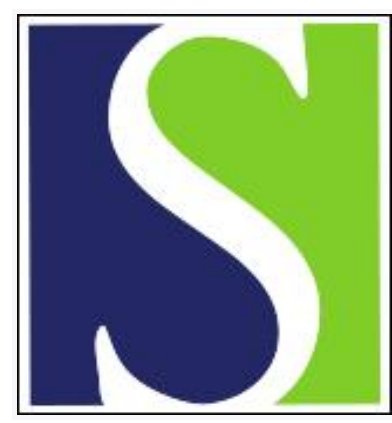

Scand J Work Environ Health 2019;45(1):1-6

https://doi.org/10.5271/sjweh.3792

Published online: 30 Nov 2018, Issue date: 01 Jan 2019

\title{
What is a psychosocial work environment?
}

by Rugulies $\mathrm{R}$

Affiliation: National Research Centre for the Working Environment, Lersø Parkallé 105, DK-2100 Copenhagen, Denmark. rer@nfa.dk

Refers to the following texts of the Journal: $2017 ; 43(4): 294-306$ 2018;44(2):183-191 2018;44(1):58-68 2017;43(4):367-374

2017;43(3):234-240 2017;43(1):50-58 2016;42(4):299-308

2015;41(3):280-287 2012;38(3):187-192 2006;32(6):473-481

The following articles refer to this text: $2021 ; 47(6): 456-465$;

2022;48(4):293-301

Key terms: conceptual framework; editorial; psychosocial; psychosocial epidemiology; psychosocial work environment

This article in PubMed: www.ncbi.nlm.nih.gov/pubmed/30643919 


\section{What is a psychosocial work environment?}

The term "psychosocial work environment" appears frequently in research articles, including those published in the Scandinavian Journal of Work, Environment and Health (1-8). Recently, the first international handbook on the emerging field of "psychosocial epidemiology" extensively addressed the contribution of psychosocial working conditions to health and illness (9).

There is, however, also a controversial debate pertaining to the meaning of the word "psychosocial" and whether it might enhance a focus on psychological phenomena and draw attention away from the work environment (10). Such concerns recently motivated the Swedish Work Environment Authority to remove the term psychosocial work environment when they published their new provision on the organizational and social work environment:

"A common term used for this work environment is psychosocial. This is a broad concept that basically refers to how the individual experiences and responds to his or her surroundings and thus the individual becomes the focus. Instead, we have chosen to highlight the organizational and social conditions and requirements at work because that is what the employer can control." (11, p12). (Translated from Swedish by the author.)

In the following, I provide some comments on this debate. I will first address the historical use of the term psychosocial work environment and then present a conceptual framework showing the relation of the psychosocial work environment to phenomena on both the societal and individual level.

\section{Historical use of the term "psychosocial work environment"}

To my knowledge, the first English-language research article using "psychosocial work environment" in the title was published in 1982. It was on "Myocardial infarction risk and psychosocial work environment: an analysis of the male Swedish working force", authored by the two Swedish researchers Lars Alfredsson and Töres Theorell and the US-American researcher Robert Karasek (12). Also in the following years, the term was mainly used in articles by Swedish/US author groups. In 1991, 21 researchers, again most of them from Sweden and the US, contributed to the book The Psychosocial Work Environment: Work Organization, Democratization and Health (13). The book was published in memory of Bertil Gardell, who held the first chair of work and organizational psychology at the Department of Psychology at the University of Stockholm from 1976 until his early death in 1987 (14). Since the 1960s, Gardell had published on topics such alienation, monotonous and deskilling work, influence and autonomy, and many articles in the book were dedicated to these factors (13). This line of research led, among other things, to the development of the demand-control (job strain) model that dominated psychosocial work environment research in the 1980s and 1990s (15).

In the 1990s and early 2000s, psychosocial work environment research increasingly included new concepts, such as balance between efforts and rewards (16), organizational justice (17), workplace social capital (18) and workplace bullying (19). One could say that psychosocial work environment research became more "psychological", in the sense that research became increasingly focused on whether or not workers feel treated fairly and respected and on the emotional effects of work tasks, procedures, or behaviors by supervisors, colleagues, clients and customers. In the Encyclopaedia of Occupational Health and Safety, published in 1998 by the International Labor Office (ILO) (20), the chapter on "Psychosocial and Organizational Factors" illustrated this broadened perspective. 
"These conditions, which are commonly referred to as psychosocial factors, include aspects of the job and work environment such as organizational climate or culture, work roles, interpersonal relationships at work, and the design and content of tasks (eg, variety, meaning, scope, repetitiveness, etc.). The concept of psychosocial factors extends also to the extra-organizational environment (eg, domestic demands) and aspects of the individual (eg, personality and attitudes), which may influence the development of stress at work. Frequently, the expressions work organization or organizational factors are used interchangeably with psychosocial factors in reference to working conditions which may lead to stress." (20, p34.32).

This quote also shows that defining "psychosocial factors" can be challenging. On the one hand, the authors regard psychosocial factors as interchangeable with "work organization". On the other hand, they point out that psychosocial factors also extend to "aspects of the individual" such as "personality and attitudes". The use of the same term for very different phenomena such as work organization and personality and attitudes is problematic in the ILO definition, and it is unclear how work organization and individual aspects are thought to be related to each other.

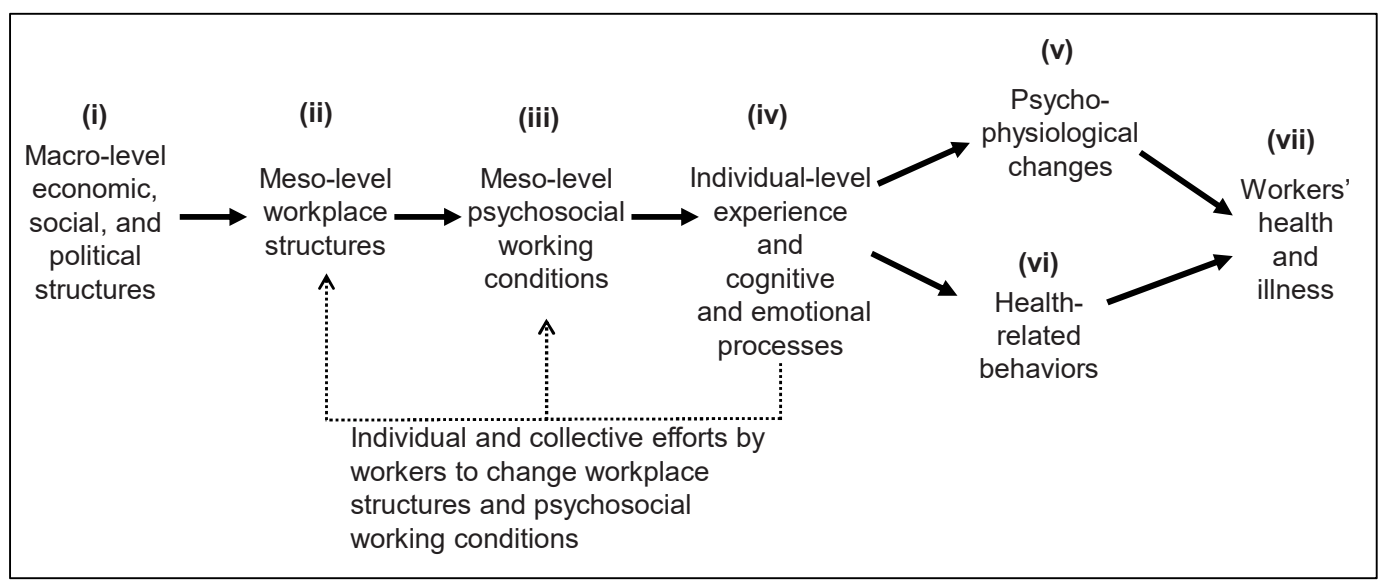

Figure 1. A conceptual framework for research on psychosocial work environment and health. Adapted and modified from previous frameworks by Martikainen et al 2002 (21) and Rugulies et al 2004 (22).

\section{A conceptual framework for research on psychosocial work environment and health}

Figure 1 shows a conceptual framework for research on psychosocial work environment and health depicting the relation of the psychosocial work environment to phenomena both on the societal and individual level. I adapted and modified the framework from two previous publications: an editorial on "Psychosocial determinants of health in social epidemiology" by Martikainen et al (21) and a book chapter on "Epidemiology of health and illness: A socio-psycho-physiological perspective" by Rugulies et al (22). Similar frameworks have been published elsewhere (23-25). The steps in the causal pathway are denoted with roman numerals to which I will refer frequently.

The pathway starts with (i) (macro-level) economic, social and political structures, such as the modes of production, division of labor, type of social welfare regime or the legal system and (ii) (meso-level) workplace structures, such as type of employment contract or adequacy of staffing that (iii) impact the meso-level psychosocial working conditions, such as job demands, work organization, content of work or social relations at work. 
These psychosocial working conditions are experienced by (iv) the individual, or group of individuals, and elicit cognitive and emotional processes. Through these processes the psychosocial working conditions subsequently evoke (v) psycho-physiological changes and (vi) health-related behaviors that (vii) affect risk of somatic diseases and mental disorders.

A challenge for psychosocial work environment research is the step from (iii) to (iv), where the working conditions "get under the skin" of the workers and are assumed to alter the workers' cognitions, emotions, behavior and physiology - a process that has also been termed as "embodiment" (26). This is a two-way process, in which not only the working conditions alter the mind and the body of the workers, but where the workers' cognitions and emotions also alter the way the workers experience working conditions (27). This raises the question to what extent the working conditions in the environment (iii) differ from the experienced working conditions by the individual (iv), a question that is in particular crucial for research that aims to ascertain psychosocial working conditions as exposures in the environment but for practical reasons measures these conditions by self-report from the individual $(28,29)$. A related question is the extent to which experiencing working conditions requires a conscious process, or if certain working conditions could be embodied while bypassing the consciousness of the individual (30).

The conceptual framework depicted in figure 1 may be useful for placing studies from different academic disciplines into a bigger picture of psychosocial work environment research, emphasizing the transdisciplinary nature of this type of research. Work environment research that is denoted as "psychosocial" is often focused on how psychosocial working conditions (iii), such as job demands, work organization, job content or social relations at work (1) are affecting psycho-physiological changes (v) (eg, stress axis activation) (31), health-related behaviors (vi) (eg, smoking or leisure time physical activity) $(32,33)$ or risk of diseases and disorders (vii), such as cardiovascular disease $(34,35)$, diabetes $(36,37)$, musculoskeletal disorders $(38)$ or depression $(39-41)$. In addition to this, the framework in figure 1 suggests that psychosocial work environment research may also include research on the historical origins of contemporary societal structures (i) (42-44) and on the impact of macro-level phenomena (i) (eg, the global financial crisis of 2007) on workers' health (vii) (45) and how this impact may be explained by changes in workplace structures (ii), for example by staff reductions, or by deteriorating working conditions and reduced job security (iii) $(46,47)$. Psychosocial work environment research may further include psychobiological research that focuses on how the cognitive and emotional processing of the individual (iv) evoke psycho-physiological changes (v) (48).

The framework in figure 1 shows a uni-directional process. Although reversed associations are possible, for example that health and illness (vii) may affect individuals' health-related behaviors (vi) or cognitive and emotional processes (iv), such bi-directional associations are intentionally not depicted to emphasize the main direction in the chain of causation from the macro-level to the meso-level to the individual-level. One exception though has been made, indicated by the dashed arrows originating from "individual-level experience and cognitive and emotional processes" and pointing to "workplace structures" and "psychosocial working conditions". These arrows are shown to acknowledge workers' individual and collective efforts to change workplace structures and working conditions. One example is the struggle of labor unions worldwide for the eight-hour work day in the $19^{\text {th }}$ and early $20^{\text {th }}$ centuries (49). Another example is what has been termed as "job crafting", that is the behaviors of workers to reduce barriers and enhance resources at work (50).

To summarize, I suggest to regard the psychosocial work environment as an intermediate step in a causal pathway linking economic, social and political structures with health and illness through psychological and psycho-physiological processes. Because of the intermediary position of the psychosocial work environment, psychosocial work environment research is not limited to "how the individual experiences and responds to his or her surroundings" (11, p12), but includes also research on the macro- and meso-level structures that determine and shape the psychosocial work environment. The psychosocial work environment is therefore a key research field for understanding how the interrelation of societal structures, environmental exposures, and psychological and psycho-physiological processes affect health and illness. 


\section{Acknowledgement}

Many thanks to my colleagues from the "Psychosocial Work Environment Research Group" at the National Research Centre for the Working Environment, Copenhagen, Denmark, for their inspiring and critical feedback on an internal discussion paper on the meaning of psychosocial work environment circulated in spring 2018. Special thanks to senior researchers Birgit Aust and Ida EH Madsen for comments to the first draft of this editorial.

\section{References}

1. Clausen T, Madsen IEH, Christensen KB, Bjorner JB, Poulsen OM, Maltesen T, et al. Reliability and validity of the Danish Psychosocial Work Environment Questionnaire (DPQ). Accepted for publication: Scand J Work Environ Health - online first. https://doi.org/10.5271/ sjweh.3793

2. Lunau T, Wahrendorf M, Müller A, Wright B, Dragano N. Do resources buffer the prospective association of psychosocial work stress with depression? Longitudinal evidence from ageing workers. Scand J Work Environ Health. 2018;44(2):183-191. https://doi. $\operatorname{org} / 10.5271 /$ sjweh.3694

3. Gupta N, Wåhlin-Jacobsen CD, Abildgaard JS, Henriksen LN, Nielsen K, Holtermann A. Effectiveness of a participatory physical and psychosocial intervention to balance the demands and resources of industrial workers: A cluster-randomized controlled trial. Scand J Work Environ Health. 2018;44(1):58-68. https://doi.org/10.5271/sjweh.3689

4. Jood K, Karlsson N, Medin J, Pessah-Rasmussen H, Wester P, Ekberg K. The psychosocial work environment is associated with risk of stroke at working age. Scand J Work Environ Health. 2017;43(4):367-374. https://doi.org/10.5271/sjweh.3636

5. Breinegaard N, Jensen JH, Bonde JP. Organizational change, psychosocial work environment, and non-disability early retirement: a prospective study among senior public employees. Scand J Work Environ Health. 2017;43(3):234-240. https://doi.org/10.5271/ sjweh.3624

6. Milner A, Krnjack L, LaMontagne AD. Psychosocial job quality and mental health among young workers: a fixed-effects regression analysis using 13 waves of annual data. Scand J Work Environ Health. 2017;43(1):50-58. https://doi.org/10.5271/sjweh.3608

7. Madsen IEH, Larsen AD, Thorsen SV, Pejtersen JH, Rugulies R, Sivertsen B. Joint association of sleep problems and psychosocial working conditions with registered long-term sickness absence. A Danish cohort study. Scand J Work Environ Health. 2016;42(4):299308. https://doi.org/10.5271/sjweh.3571

8. Schioler L, Soderberg M, Rosengren A, Jarvholm B, Toren K. Psychosocial work environment and risk of ischemic stroke and coronary heart disease: a prospective longitudinal study of 75236 construction workers. Scand J Work Environ Health. 2015;41(3):280-287. https://doi.org/10.5271/sjweh.3491

9. Kivimäki M, Batty GD, Steptoe A, Kawachi I, editors. The Routledge international handbook of psychosocial epidemiology. New York: Routledge; 2018.

10. Muntaner C, Chung HJ. Psychosocial epidemiology, social structure, and ideology. J Epidemiol Community Health. 2005;59(7):540-541.

11. Arbetsmiljöverket (Swedish Work Environment Authority). Den organisatoriska och sociala arbetsmiljön - viktiga pusselbitar i en god arbetsmiljö. Vägledning till Arbetsmiljöverkets föreskrifter om organisatorisk och social arbetsmiljö, AFS 2015:4. [The organisational and social work environment - important pieces of puzzle in a good work environment. Guidance to the Work Environment Authority's provisons on organizational and social work environment]. Stockholm: Arbetsmiljöverket, 2016. Available from: https://www.av.se/ arbetsmiljoarbete-och-inspektioner/publikationer/bocker/vagledning-organisatorisk-social-arbetsmiljo-h457/ (Accessed: 19 November 2018).

12. Alfredsson L, Karasek R, Theorell T. Myocardial infarction risk and psychosocial work environment: an analysis of the male Swedish working force. Soc Sci Med. 1982;16(4):463-467. https://doi.org/10.1016/0277-9536(82)90054-5

13. Johnson JV, Johansson G, editors. The psychosocial work environment: Work organization, democratization and health. Amityville, NY: Baywood Publishing Company; 1991.

14. Department of Psychology. Homepage of the division of work and organizational psychology. Stockholm University; 2018. Available from: https://www.psychology.su.se/english/research/research-areas/work-and-organizational-psychology. (Accessed: 19 November 2018).

15. Karasek R, Theorell T. Healthy work: stress, productivity, and the reconstruction of working life. New York: Basic Books; 1990.

16. Siegrist J. Adverse health effects of high-effort/low-reward conditions. J Occup Health Psychol. 1996;1(1):27-41. https://doi. org/10.1037/1076-8998.1.1.27

17. Elovainio M, Kivimäki M, Vahtera J. Organizational justice: evidence of a new psychosocial predictor of health. Am J Public Health. 
2002;92(1):105-108. https://doi.org/10.2105/AJPH.92.1.105

18. Kouvonen A, Kivimäki M, Vahtera J, Oksanen T, Elovainio M, Cox T, et al. Psychometric evaluation of a short measure of social capital at work. BMC Public Health. 2006;6:251. https://doi.org/10.1186/1471-2458-6-251

19. Einarsen S, Skogstad A. Bullying at work: Epidemiological findings in public and private organizations. European Journal of Work and Organizational Psychology. 1996;5(2):185-201. https://doi.org/10.1080/13594329608414854

20. Sauter SL, Murphy LR, Hurrell JJ, Levi L. Psychosocial and organizational factors. In: Stellman JM, editor. ILO Encyclopedia of Occupational Health and Safety. Geneva: International Labour Office; 1998. p. 34.32-34.33. Available from: http://www. iloencyclopaedia.org/part-v/psychosocial-and-organizational-factors/item/9-psychosocial-and-organizational-factors. (Accessed: 19 November 2018).

21. Martikainen P, Bartley M, Lahelma E. Psychosocial determinants of health in social epidemiology. Int J Epidemiol. 2002;31(6):10911093. https://doi.org/10.1093/ije/31.6.1091

22. Rugulies R, Aust B, Syme SL. Epidemiology of health and illness: A socio-psycho-physiological perspective. In: Sutton S, Baum A, Johnston M, editors. The Sage handbook of health psychology. London: Sage; 2004. p. 27-68.

23. Rugulies R. Invited commentary: Structure and context matters--the need to emphasize "social" in "psychosocial epidemiology". Am J Epidemiol. 2012;175(7):620-624. https://doi.org/10.1093/aje/kws033

24. Dahlgreen G, Whitehead M. European strategies for tackling social inequalities in health. Levelling up: Part 2.Copenhagen: WHO Regional Office for Europe, 2006. Available from: http://www.euro.who.int/_data/assets/pdf_file/0018/103824/E89384.pdf (Accessed: 19 November 2018).

25. Schnall PL, Dobson M, Landsbergis P. Globalization, work, and cardiovascular disease. Int J Health Serv. 2016;46(4):656-692. https:// doi.org/10.1177/0020731416664687

26. Krieger N. Embodiment: a conceptual glossary for epidemiology. J Epidemiol Community Health. 2005;59(5):350-355. https://doi. org/10.1136/jech.2004.024562

27. Frese M, Zapf D. Methodological issues in the study of work stress: Objective vs subjective measurement of work stress and the question of longitudinal studies. In: Cooper CL, Payne R, editors. Causes, coping and consequences of stress at work - Wiley series on studies in occupational stress. Chichester, England: John Wiley \& Sons; 1988. p375-411.

28. Kasl SV. Measuring job stressors and studying the health impact of the work environment: an epidemiologic commentary. J Occup Health Psychol. 1998;3(4):390-401. https://doi.org/10.1037/1076-8998.3.4.390

29. Rugulies R. Studying the effect of the psychosocial work environment on risk of ill-health: towards a more comprehensive assessment of working conditions. Scand J Work Environ Health. 2012;38(3):187-192. https://doi.org/10.5271/sjweh.3296

30. Greiner BA, Krause N, Ragland D, Fisher JM. Occupational stressors and hypertension: a multi-method study using observerbased job analysis and self-reports in urban transit operators. Soc Sci Med. 2004;59(5):1081-1094. https://doi.org/10.1016/j. socscimed.2003.12.006

31. Kivimäki M, Steptoe A. Effects of stress on the development and progression of cardiovascular disease. Nat Rev Cardiol. 2018;15(4):215229. https://doi.org/10.1038/nrcardio.2017.189

32. Fransson EI, Heikkilä K, Nyberg ST, Zins M, Westerlund H, Westerholm P, et al. Job strain as a risk factor for leisure-time physical inactivity: an individual-participant meta-analysis of up to 170,000 men and women: the IPD-Work Consortium. Am J Epidemiol. 2012;176(12):1078-1089. https://doi.org/10.1093/aje/kws336

33. Siegrist J, Rödel A. Work stress and health risk behavior. Scand J Work Environ Health. 2006;32(6):473-481. https://doi.org/10.5271/ sjweh. 1052

34. Kivimäki M, Nyberg ST, Batty GD, Fransson EI, Heikkilä K, Alfredsson L, et al. Job strain as a risk factor for coronary heart disease: a collaborative meta-analysis of individual participant data. Lancet. 2012;380(9852):1491-1497. https://doi.org/10.1016/S01406736(12)60994-5

35. Dragano N, Siegrist J, Nyberg ST, Lunau T, Fransson EI, Alfredsson L, et al. Effort-reward imbalance at work and incident coronary heart disease: a multi-cohort study of 90,164 individuals. Epidemiology. 2017;28(4):619-626. https://doi.org/10.1097/ EDE.0000000000000666

36. Nyberg ST, Fransson EI, Heikkilä K, Ahola K, Alfredsson L, Bjorner JB, et al. Job strain as a risk factor for type 2 diabetes: a pooled analysis of 124,808 men and women. Diabetes Care. 2014;37(8):2268-2275. https://doi.org/10.2337/dc13-2936

37. Kivimäki M, Virtanen M, Kawachi I, Nyberg ST, Alfredsson L, Batty GD, et al. Long working hours, socioeconomic status, and the risk of incident type 2 diabetes: a meta-analysis of published and unpublished data from 222120 individuals. Lancet Diabetes Endocrinol. 2015;3(1):27-34. https://doi.org/10.1016/S2213-8587(14)70178-0

38. Hauke A, Flintrop J, Brun E, Rugulies R. The impact of work-related psychosocial stressors on the onset of musculoskeletal disorders in specific body regions: A review and meta-analysis of 54 longitudinal studies. Work Stress. 2011;25(3):243-256. https://doi.org/10.1080/02678373.2011.614069

39. Theorell T, Hammarström A, Aronsson G, Träskman Bendz L, Grape T, Hogstedt C, et al. A systematic review including meta-analysis of work environment and depressive symptoms. BMC Public Health. 2015;15(1):738. https://doi.org/10.1186/s12889-015-1954-4 
40. Madsen IEH, Nyberg ST, Magnusson Hanson LL, Ferrie JE, Ahola K, Alfredsson L, et al. Job strain as a risk factor for clinical depression: systematic review and meta-analysis with additional individual participant data. Psychol Med. 2017;47(8):1342-1356, https://doi.org/10.1017/S003329171600355X

41. Rugulies R, Aust B, Madsen IEH. Effort-reward imbalance at work and risk of depressive disorders. A systematic review and metaanalysis of prospective cohort studies. Scand J Work Environ Health. 2017;43(4):294-306. https://doi.org/10.5271/sjweh.3632

42. Hobsbawm E. The age of revolution. 1789-1848. London: Weidenfeld \& Nicholson; 1962.

43. Hobsbawm E. The age of capital. 1848-1875. London: Weidenfeld \& Nicholson; 1975.

44. Hobsbawm E. The age of empire. 1875-1914. London: Weidenfeld \& Nicholson; 1987.

45. Karanikolos M, Heino P, McKee M, Stuckler D, Legido-Quigley H. Effects of the global financial crisis on health in high-income OECD countries: A narrative review. Int J Health Serv. 2016;46(2):208-240. https://doi.org/10.1177/0020731416637160

46. Torá I, Martínez JM, Benavides FG, Leveque K, Ronda E. Effect of economic recession on psychosocial working conditions by workers' nationality. Int J Occup Environ Health. 2015;21(4):328-332. https://doi.org/10.1080/10773525.2015.1122369

47. European Foundation for the Improvement of Living and Working Conditions. Impact of the crisis on working conditions in Europe.2013. Available from: https://www.eurofound.europa.eu/sites/default/files/ef_files/docs/ewco/tn1212025s/tn1212025s.pdf (Accessed: 19 November 2018).

48. Ursin H, Eriksen HR. The cognitive activation theory of stress. Psychoneuroendocrinology. 2004;29(5):567-592. https://doi. org/10.1016/S0306-4530(03)00091-X

49. International Labor Organization. International labour standards on working time. 2018. Available from: http://www.ilo.org/global/ standards/subjects-covered-by-international-labour-standards/working-time/lang--en/index.htm. (Accessed: 19 November 2018).

50. Nielsen K, Abildgaard JS. The development and validation of a job crafting measure for use with blue-collar workers. Work Stress. 2012;26(4):365-384. https://doi.org/10.1080/02678373.2012.733543

Reiner Rugulies ${ }^{1,2,3}$

${ }^{1}$ National Research Centre for the Working Environment

${ }^{2}$ Department of Public Health, University of Copenhagen, Denmark

${ }^{3}$ Department of Psychology, University of Copenhagen, Denmark

\section{Correspondence to:}

Reiner Rugulies, PhD, MSc, MPH

National Research Centre for the Working Environment

Lersø Parkallé 105

DK-2100 Copenhagen

Denmark

[Email: rer@nfa.dk] 